\title{
Enhancing Quality of Education in the University System: A Study of Nigerian Education System
}

\author{
Adekunle Thomas Olutola ${ }^{1}$, Rafiu Ademola Olatoye ${ }^{2}$ \\ ${ }^{1,2}$ Department of Educational Foundations, Faculty of Education, \\ Federal University Dutsin-Ma, Katsina State, Nigeria. \\ aolutola@fudutsinma.edu.ng ${ }^{1}$
}

DOI: https://doi.org/10.37134/ajatel.vol10.2.6.2020

Received: 15 June 2020; Accepted: 8 August 2020; Published: 16 August 2020

Cite this article (APA): Olutola, A. T., \& Olatoye, R. A. (2020). Enhancing quality of education in the university system: A study of Nigerian education system. Asian Journal of Assessment in Teaching and Learning, 10(2), 5561. https://doi.org/10.37134/ajatel.vol10.2.6.2020

\begin{abstract}
How to enhance and maintain quality of education in Nigerian University education system has become one of the central issues in educational assessment and evaluation. It is important to note that no nation can rise above the standard of her education. The quality of education in Nigeria is presently rated as low. Many scholars have observed that many graduates are unemployable because they lack relevant and required skills. Therefore, this paper examines the present educational quality in Nigeria, reasons for the current trend, assessment issues, advantages and disadvantages of computer-based tests in the university system, recruitment of staff without thorough assessment and politics of accreditation in Nigeria. It was concluded that the quality of education in the University system can be enhanced and maintained through qualitative assessment. Also, there is the need to review the process of recruitment of staff, accreditation procedures, monitoring and evaluation of standard as well as students' assessment practices.
\end{abstract}

Keywords: Quality, Education, University System, Qualitative Assessment

\section{INTRODUCTION}

Quality education is a crucial tool for improving the prospects of higher income levels for individuals and for economic growth of nations. University education has a major role to play in enhancing quality of education, level of development and progress of any nation and the world in general. It is the responsibility of the University education system to ensure that the skills, understanding and values acquired by students are enough to make them employable. Quality education ensures that students are well equipped with knowledge and skills that make them to be useful and relevant in the society.

Goal 4 of the United Nations Sustainable Development Goals (SDGs) is focused on ensuring inclusive and equitable quality education and promoting life-long learning opportunities for all (Centre for the Study of Economics of Africa, CSEA, 2018). However, qualitative education cannot be achieved without proper assessment of students and educational programmes.

Assessment involves the collection of information about an individual's knowledge, skills, attitudes, judgment, interpretation and using the data for taking relevant decisions about the individual, instructional process, curriculum or programme (Ugodulunwa, 2008). Anikweze (2013) defines assessment to include teacher, peer and self-assessment processes where the goal is to develop new models of assessment geared towards fostering life-long skills. Because assessment covers all aspects of school learning, teachers must be skilled in different techniques of assessment.

The essence of assessment is to ensure quality, improve teaching methods and students' performance. The present quality of education in Nigeria is a serious concern to all the stakeholders in educational setting. Studies revealed that most of high-quality universities listed in the top 20 universities of the world are established in the developed nations such as USA, Germany, Britain and 
France. These universities have also produced about 70 percent of the Nobel Prize winners of the world. Their graduates hold most of the prestigious positions in the public and private institutions, the governments and the global institutions. They are able to recruit, relatively, higher quality faculty and students of the global talent pool. They are also able to have the largest financial resources and endowments like Universities of Harvard, Stanford, Princeton, Cambridge, Oxford (The Economist, 2011). They all have the major characteristics of the high quality university. They have the high quality academic programmes, high quality teaching faculty members, and the high quality students. Most of their faculties are engaged in quality research and produce the high quality and quantity of new knowledge and publications. Their graduates obtain the most high quality professional positions and generate the largest physical and financial resources and endowments for supporting themselves. They produce the most of the Noble-prize winners in the sciences (The Economist, 2011).

The major concern of all stakeholders in Nigeria is the provision of quality education. Quality is judged by assessing the degree to which the intended outcomes are achieved. University has a responsibility to achieve and maintain the quality of their educational programmes in order to achieve the aim and objective of such programme. Quality in University education involves three important elements input, process and outcomes. Input involves the learners, lecturers and the administrative staff and essential facilities for teaching and learning, process is the teaching and learning of various activities and outcomes are products.

Moreover, Adegbesan (2010) enunciated the major needs of quality assurance in Nigeria's education system thus:

a) To serve as indispensable component of quality control strategy in education;

b) To ensure and maintain high standard of education at all levels;

c) To assist in monitoring and supervision of education;

d) To determine the quality of the teacher input in order to produce quality outcome;

e) To determine the number of classrooms needed based on the average class size;

f) To determine the level of adequacy of the facilities available for quality control;

It would ensure how the financial resources available could be prudently and judiciously utilized.

It is important to note that Nigeria Universities are facing a lot of problems in term of quality education. Archibong (2013) observed that Nigerian public universities have not fared well with respect to quality education delivery due largely to rapid expansion of universities within a very short span of time, inadequate funding, poor management culture, infrastructural decay, examination malpractice, increased students population and so on. The quality of University education is crucial to economic and development growth of any nation.

\section{THE PRESENT LEVEL OF EDUCATIONAL QUALITY IN NIGERIA}

Some the products of present level of educational quality in Nigeria are:

1. Half-baked graduates: A good quality graduate is an individual that can be depended upon to carry out certain leadership assignment without much supervision. Above all, a good quality graduate is a leader of people and manager of resources. He is an individual the society looks up to for guidance and direction. Okebukola as cited Onuoch aand Ewuzie (2012) states that the worth of a university degree is the depth of knowledge, skills, attitudes and values which the graduate bears as consequence of his education. The graduate is expected to demonstrate complementary skills such as reflective and critical thinking, interpersonal and team skills as well as communication and organizational skills (Onuocha \& Ewuzie, 2012). Some of the Nigeria graduates cannot speak English language, are unemployable, lack reflective and critical thinking, have inadequate communication, organizational and employable skills which make them to be described as half- baked graduates'.

2. Unemployable graduates: According to Asiyai and Oghuvbu (2009) defined quality as a measure of how good or bad the products of higher education institutions in Nigeria are in terms 
of their academic performance and meeting established standards. Quite a number of graduates in Nigeria are unemployable because of poor quality of education and assessment they were exposed to.

\section{OVERVIEW OF CURRENT TREND IN NIGERIAN EDUCATIONAL SYSTEM}

Some of the reasons for current trend in Nigerian educational system are discussed below:

\section{Examination malpractice}

Examination malpractice has become a serious worry to all the stakeholders in education sector. In fact, it has put question mark on the quality of education in Nigeria. Examination malpractice is already becoming a culture in Nigerian educational scene because it is being condoned by most parents, students, teachers and lecturers (Ojerinde, 2010). The incidence of examination malpractice has become endemic and the penalty given to its perpetrators has no significant effects on them. As a result of frequent cases of examination malpractice, the society is losing confidence in the certificates awarded by some institutions and examination bodies (Emaikwu \& Eba, 2007; Ogum, 2007)

\section{Infrastructure Decay}

There is decay in infrastructure in Nigeria Universities. The facilities are inadequate and not in good condition for usage. When there is no quality infrastructures in the university system, to achieve quality education will be difficult.

\section{Academic Staff Union of Universities (ASUU) Strike}

Government should endeavour to eliminate ASUU strike in order to achieve and maintain quality education in Nigeria. Academic Staff Union of Universities (ASUU) incessant strikes should be checked. Government-owned Universities should emulate private school owners by avoiding strikes. This will give students enough time to study so that they can be able to face challenges in the labour market and in order not to make quality education in Nigeria a mirage.

University education in Nigeria has thus suffered serious setbacks as a result of teachers' strike actions. This has always resulted to disruption of academic calendars, giving student's undeserved extension in their study years, poor students' concentration on academic programmes and poor teacherstudent relationships amongst others (Edinyang \& Ubi, 2013).

\section{Lack of Stable Academic Calendar}

This has done a great damage to the quality of education in Nigeria. A situation where students who supposed to spend four years on a programme in Nigeria University now spend eight years or above. This is causing a lot of damage to our educational system. Lack of stable academic calendar is caused by ASUU and Labour strikes which can be eliminated in order to maintain quality in our education and assessment processes.

\section{Lack of Accountability}

Some of the University managements are not good managers of the resources given to them by governments to develop University and improve infrastructures facilities. Accountability is normally linked with the management of scarce resources of education to ensure product utilization of available resources for the accomplishment of goals of education. This will ensure service delivery, control indiscipline and thereby increase efficiency (Nakpodia \& Okeimute, 2011); Usman, (2016).

The Governing Council of the Universities and the University management should ensure that money released by the government (in case of public universities) and Internally Generated Revenue 
(IGR) are used to procure resources that can enhance quality and expenditure in the Universities should be made public to stakeholders for scrutiny.

\section{Poor Funding}

Inadequate funding of the education sector in Nigeria has affected the quality of education. Nigerian leaders should embrace the UNESCO recommendation for funding education. Adequate funding is required and necessary to maintain both the human and material resources of the University in other to improve the quality of education sector. Funding helps in maintenance of the physical facilities that have become a problem to both the learning and living conditions of students.

Ogbogu (2011) recommended that proactive mechanisms that facilitate identification of multiple sources of funding as well as their optimal utilization in order to ensure quality of education should be employed. University administrators should therefore think outside the box to facilitate generation of funds to meet the ever-increasing needs in the University.

In addition, according to Obasi (2010) the indicators of quality and functional education are:

a. Effective and efficient performance of graduates in society, industries and other work places.

b. Employability (self, national and international) of products/graduates (Entrepreneurship level)/ Graduate employment statistics.

c. National and International mobility of generated manpower.

d. Market value or demand level of research products and other services provided by the institutions.

e. Level of discipline and patriotism of graduates.

f. International transferability/admissibility of graduates/students for higher studies without remedial conditions.

g. High rating of an institution and its products nationally and internationally.

h. High absorptive capacity at all levels.

All the above indicators of quality and functional education are either lacking or inadequate in Nigeria Universities.

\section{PROBLEM OF ASSESSMENT}

Assessment has faced a lot of problems in Nigeria, as follows.

\section{Inadequate facilities, quality and quantity faculty members}

Many universities in Nigeria do not have facilities that can enhance quality of education. They do not have sufficient high quality and quantity faculty; they cannot keep the quality faculty for a long time and cannot provide sufficient faculty salaries and research funds to attract and keep the high quality faculty staff.

They do not have enough physical and financial resources to support a variety of quality programs, majors, courses, and appropriate class sizes, libraries, laboratories, research activities, and other facilities that are required for the high quality university. As a result of these problems, many universities in many nations do not provide the high quality higher education. large classes, high lecturer-students ratio, grading of students through $\mathrm{CA}$ which is not thoroughly done again in our universities.

\section{Recruitment of Staff}

The recruitment of staff in Nigeria Universities has been mar with ethnicity. Recruitment of staff in Nigeria University is now done without through assessment which has really affected the quality of education in our tertiary institutions. In addition, the recruitment of staff has been politicized and 
majority of staff in our Universities are in-house bred. Employment is made based on ethnicity and religion. This has affected the quality of Nigeria assessment in Nigeria.

Findings from a study conducted by Yaro (2014) showed that sentiment and other primordial issues like ethnicity, nepotism and favouritism are given more consideration in terms of employment than merit. Political interference and undue influence are constant features of recruitment in Nigeria. This is dangerous and a serious threat to quality in the University system which is expected to attract best brains to mould the up-coming generations.

\section{Politics of Accreditation in Nigeria}

Politics has been part and parcel of Nigerian educational system. No accreditation process in Nigerian universities is devoid of politics. Harold (2010) defines politics as a system of who gets what, when and how. Politics of accreditation in universities include, but not limited to the following:

a) Politics of panel composition: this is the panel assigned by NUC to assess University programmes. Utuka (2011) observed that some panel chairmen usually take full control of discussions and can be influenced financially by the host university authorities. Based on this, the decision of the panel members can be compromised in favour of the institution.

b) Politics of Borrowing needed facilities: Some universities engage in unethical practices during accreditation exercise such as borrowing books into the libraries while facilities/equipment are also borrowed stock the laboratories. The borrowed facilities usually have the name of the real owners. Otokunefor (2013) reported that facilities are brought overnight to be put in the departments before accreditation and disappear immediately after the exercise, an indication that the facilities have been returned to the owners.

c) Staff politics: During accreditation exercise, some universities usually hire senior staff for the purpose of the exercise. These staff will go back to their different universities after the accreditation exercise. This is unethical practice and is destroying the quality of our assessment.

An empirical study carried out on accreditation by Ekpoh and Edet (2017) showed that books are borrowed to boost library stock and there is window dressing of facilities just to pass accreditation by all means. The implication of this is that many programmes would have passed accreditation without necessarily possessing the minimum required facilities by the regulating bodies. This in turn will affect the quality of graduates produced by Universities running such programmes. The implication of this on the practice of graduate professionals like lawyers, doctors, engineers to mention a few are very grievous.

\section{PROS AND CONS OF COMPUTER BASED TESTS (CBT) IN THE UNIVERSITY}

CBT can be defined as tests or assessments that are administered by computer in either stand-alone or dedicated network or by other technology devices linked to the internet or World Wide Web, most of them using Multiple Choice Questions (MCQs) (Sorana-Daniela \& Lorentz, 2007).

McConnell and Schoenfeld-Tachner (2001) viewed Computer-Based Test as a way to increasingly provide a quick method of marking summative assessments for large groups of students. Computer-based test is the logical extension of computer-enhanced learning. The introduction of computer-based test by Nigeria examination bodies like Joint Admission Matriculation Board (JAMB) and other examination bodies such as NECO, WAEC and NABTEB has brought innovation into the process of assessment. This is part of the efforts made by examination bodies in Nigeria to ensure quality in assessment. 


\section{ADVANTAGES OF CBT}

Computer-based tests offer several benefits such as:

a) It is easy to administer,

b) It is easy to mark and score,

c) Its scoring is reliable due to objectivity,

d) It provides immediate feedback for decision-making,

e) It minimizes test leakage, and

f) It covers wide range of the course content or syllabus.

\section{DISADVANTAGES OF CBT}

The following are the disadvantages of CBT:

a) It is difficult to construct CBT items with plausible options or alternatives,

b) It encourages guessing of correct answers,

c) It fails to assess the testee's power of self-expression

d) Setting of good items is time-consuming

e) It focuses on result and not on the process

\section{CONCLUSION}

It is important to recognize that quality education is a key to development and growth in any country including Nigeria. It is highly embarrassing that some of the products of Nigeria University cannot compete favourably with those of many other universities in the world in terms of research, technological advancement and employability skills. All the stakeholders in education sectors should come together to solve the problems of quality education Nigeria. Without quality education, our graduates will continue to be half-baked, unproductive and unemployable which in turn limit the growth and development of our society and country in general.

\section{RECOMMENDATIONS}

The following recommendations were made:

1. Government should motivate teaching staff with better salary package so that they can happily be committed to their duties without engaging in any business or other trades in order sustain their well-being.

2. Conducive environment should be created to facilitate teaching and learning process and provision of appropriate, well -equipped and adequate laboratories, classrooms, libraries, and staff offices.

3. ASUU and labour strikes should be completely eliminated in order to promote quality in our university system.

4. Instructional materials be provided and supplied to all the Nigerian Universities to facilitate teaching and learning activities.

5. Accreditation process should be thoroughly done without favourism and compromise in order to maintain standard.

6. Examination bodies in Nigeria should improve on the use of computer-based tests (CBT) for better assessment outcome and to enhance better innovation in the assessment process. 
7. Government should from now be committed to quality of University education by adequately financing the education sector and prioritize infrastructure rehabilitation in Nigerian University which in turns will improve quality and students' performance. Budget for education should be higher than the budget for any other sector.

\section{REFERENCES}

Adegbesan, O. (2010). Quality assurance and sustainable university education in Nigeria. A paper presented at a workshop at the University of Lagos, Akoka-Yaba, Lagos, Lagos State, Nigeria.

Anikweze, C.M. (2013). Assessment Practices and the Challenges of Innovations in Nigerian Education. Being a Paper Presented at an Institutional Seminar Organized by the Joint Admissions and Matriculation Board (JAMB), Abuja on $3^{\text {rd }}$ September, 2013 at the JAMB Auditorium.

Archibong, I. A. (2013). Strengthening internal quality assurance for improved education delivery in Nigerian public universities. Research on Humanities and Social Sciences, 3(1), 172 - 178.

Asiyai RI and Oghuvbu EP (2009) An empirical analysis of the causes and possible solutions to decline in quality of tertiary education in Delta State, Nigeria. Journal of Sociology and Education in Africa, 8(2):1-13.

CSEA (2018). Nigeria: Achieving Quality Education for All in Nigeria. CSEA, Dhake.

Edinyang, S. D and Ubi, I. E., 2013. Effect of strike action on human development among social Studies secondary school students in Uyo local government Area of Akwa Ibom State, Nigeria. Global Journal of Human Resource Management, 1, (2): $1-8$.

Ekpoh, U. I. \& Edet, A. O. (2017). Politics of pragramme accreditation practices in Nigerian Universities: Implications for quality assurance. Journal of Educational and Social Research, 7 (2), 73-79.

Emaikwu, S.O. \& Eba, E. (2007). Examination malpractices in tertiary institutions: Implications and the way forward. In Akubue, A.U. \& Enyi, D. (Ed.) (389-400) Crises and Challenges in Higher Education in Developing Countries. A Publication of the Department of Educational Foundations, University of Nigeria, Nsukka.

Harold, L. (2010). What is politics? Retrieved from ordinary-gentlemen.com/2010/12.

McConnell, S. and Schoenfeld-Tachner, R. (2001) Transferring your passion for teaching to the online environment: A five step instructional development model. E-Journal of Instructional Science \& Technology, 4, 1 .

Nakpodia, E.D. and Okeimute, A. R. (2011). Teachers' accountability in Nigeria education system: Perception of teachers and administrators in Delta State. International NGO Journal, 6(7), Pp. 152-158.

Obasi, O. (2010). Qualitative and functional education as a social imperative for authentic national development: The Nigerian situation. School of Business and Management Technology Conference Journal, 1(1): 514.

Ogum, D.N. (2007). On the declining literacy among trainee teachers in Nigeria. African Journal of Educational Development Studies 4 (1), 143-149.

Ogbogu, O. C. (2011). Modes of Finding Nigerian Universities and the Implications on Performance. Journal of International Educational Research, 7(4), 75-82.

Ojerinde, B.B. (2010). Examination and students' performance. Vanguard, January16, p. 30.

Onuocha, I. and Ewuzie, K. (2012) "Employers Worry as Nigerian Degrees Face Quality Test", in Business Day, September 14th.

Otokunefor, T. (2013). NUC's sham Accreditation. Retrieved from nationalmirroronlinenetnew/nuc's-shamaccreditation

Yaro, I. (2014). Recruitment and Selection in the Nigerian public service: Nature, challenges and way forward. British Journal of Economics, Management and Trade, 4 (7), 1005-1017.

Sorana-Daniela B, \& Lorentz J (2007). Computer-based testing on physical chemistry topic: A case study. Inter. J. Educ. Develop. using Info. Com. Technol., 3(1): 94-95.

The Economist (2011). The Global Campus. January 22nd- 28th, pp. 14-17.

Ugodulunwa, C.A. (2008). Fundamentals of educational measurement and evaluation. Jos: Fab Anieh Nig. Ltd.

Usman, Y. D. (2016). Accountability in education: An imperative for service delivery in Nigerian school systems. Akwanga Journal of Education and Research (AJER), 1, (1), Pp. 264-272.

Utuka, G. (2011). Demonstrating quality evaluation of institutional and programme accreditation in Ghana. 